\title{
KAJIAN SEMIOTIKA SIMBOL BUDAYA KERATON SURAKARTA DALAM IKLAN KUKU BIMA ENER-G VERSI VISIT JAWA TENGAH
}

\section{SEMIOTICS ANALYSIS OF CULTURAL SYMBOL FROM SURAKARTA PALACE ON ADVERTISEMENT OF KUKU BIMA ENER-G VISIT CENTRAL JAVA VERSION}

\author{
Anintya Wanda Permana ${ }^{a}$, Ana Rosmiati ${ }^{b}$ \\ ${ }^{\text {ab }}$ Program Studi Magister Pengkajian Seni, Pascasarjana Institut Seni Indonesia, Surakarta \\ Jl. Ki Hajar Dewantara No. 19, Kentingan, Jawa Tengah. 57126. \\ Pos-el anintyawp30@gmail.com; ana.rosmiatii@yahoo.com
}

\begin{abstract}
Advertisement is a media which use by company to promote their product. Packaging and display of advertising made with interested to attract consumen interest. Some advertisement also showing some of local wisdom unsure in their display, one of them is the advertisement of Kuku Bima Ener-G Visit Central Java version which including the display of Surakarta Palace culture. Purposes of this research are to describe and explain about cultural symbol of Surakarta Palace on advertisement of Kuku Bima Ener-G Visit Central Java version. Form of this research is qualitative descriptive using semiotic approach of Roland Barthes. Primary data resource is advertisement of Kuku Bima Ener-G $V$ isit Central Java version, secondary data are some reference which related with data analysis and some informant from cultural expert. Data collected using listen-noted technique and in-depth interview. Data analysis tecbnique using interactive technique. Result of this research find fifth frame on advertisement of Kuku Bima Ener-G Visit Central Java version which contain cultural symbol of Keraton Surakarta. Each symbol on frame have denotative and connotative meaning. Some frame of that advertisement represented the Keraton Surakarta culture, that are Manipuri Dance, Panggung Sangga Buwana building, Kori Kamandungan, kirab ceremonial procession, traditional food of tumpeng sari, and keris as traditional weapon from Surakarta.
\end{abstract}

Keywords: semiotics analysis, cultural symbol, Keraton Surakarta, Advertisement of Kuku Bima Ener-G Visit Central Java version

\begin{abstract}
Abstrak
Iklan merupakan media yang digunakan oleh perusahaan untuk memasarkan produknya. Kemasan dan tampilan iklan dibuat semenarik mungkin untuk menarik minat konsumen. Iklan juga tidak jarang menampilkan unsur kearifan lokal dalam tayangannya, salah satunya adalah iklan Kuku Bima Ener-G versi Visit Jawa Tengah yang memasukkan tampilan budaya Keraton Surakarta. Tujuan penulisan artikel ini adalah mendeskripsikan dan menjelaskan simbol budaya Keraton Surakarta dalam iklan Kuku Bima Ener-G versi Visit Jawa Tengah. Penelitian ini berbentuk penelitian kualitatif deskriptif dengan menggunakan pendekatan semiotika Roland Barthes. Sumber data primer adalah iklan Kuku Bima Ener-G versi Visit Jawa Tengah, sumber data sekunder berupa referensi yang terkait dan informan yang diambil dari kalangan ahli budaya Keraton Surakarta. Pengumpulan data menggunakan teknik simak-catat dan wawancara mendalam. Teknik analisis data menggunakan teknik analisis interaktif. Dari hasil penelitian ini, ditemukan 5 lima frame dari iklan Kuku Bima Ener-G versi Visit Jawa Tengah yang memuat unsur budaya Keraton Surakarta. Tiap-tiap frame mengandung simbol budaya yang bersumber dari Keraton Surakarta. Tiap-tiap simbol budaya tersebut memiliki makna denotatif dan makna konotatif. Beberapa frame iklan tersebut yang merepresentasikan budaya Keraton Surakarta,
\end{abstract}


yaitu Tari Manipuri, bangunan panggung Sangga Buwana dan Kori Kamandungan, proses upacara kirab, makanan tradisional tumpeng sari, dan senjata tradisional yang berupa keris gaya Surakarta.

Kata kunci: kajian semiotika, simbol budaya, Keraton Surakarta iklan Kuku Bima Ener-G versi Visit Jawa Tengah

\section{PENDAHULUAN}

Industri periklanan di Indonesia semakin berkembang pesat dengan ditandai makin marak dan kreatifnya iklan-iklan yang ada di televisi. Iklan di televisi dianggap sebagai salah satu sarana yang efektif untuk memasarkan dan mengenalkan suatu produk karena hampir setiap masyarakat Indonesia memiliki televisi dan menonton siaran televisi sehingga dengan menggunakan tayangan iklan di televisi diharapkan produk yang ditawarkan akan diketahui oleh masyarakat luas (Malika \& Lestari, 2018: 3). Estetika dan keindahan suatu iklan sangat ditentukan oleh produser dari program iklan. Suatu program iklan haruslah memiliki ciri khusus yang membedakan dengan iklan-iklan yang lain. Ciri khusus tersebut dapat dilihat dari format iklan, hal yang lebih ditonjolkan dalam iklan, pendekatan yang digunakan dalam sajian iklan, dan beberapa unsur lain yang terkait dengan tayangan iklan. Mengenai iklan televisi, Bungin (2011: 40-41) berpendapat bahwa dalam tampilannya iklan televisi membangkitkan citra produk yang diiklankan maka digunakan simbolsimbol untuk membangun citra, makna dan kesadaran terhadap sebuah realitas sosial. Simbolsimbol yang dimaksud adalah simbol-simbol yang menjadi acuan di masyarakat atau dengan kata lain adalah simbol-simbol yang dimodernkan oleh masyarakat. Pendapat tersebut dijadikan landasan dalam penelitian ini, yaitu mengenai simbolsimbol dalam iklan yang memuat citra produk dan harus diterjemahkan oleh masyarakat luas sebagai konsumen produk.

Simbol-simbol yang ditampilkan dalam iklan televisi tidak jarang memuat simbol-simbol yang merepresentasikan budaya lokal. Simbol tentang budaya lokal tersebut ditampilkan dalam rangka menyosialisasikan kebudayaan Indonesia. Hal ini tidak terlepas dengan fenomena merosotnya budaya Indonesia di masyarakat. Banyak dari masyarakat Indonesia yang tidak paham dan tidak mengerti mengenai budaya lokal atau budaya daerahnya. Kebanyakan dari mereka lebih memilih untuk mempelajari budaya asing yang dianggap lebih modern dan dapat mengikuti perkembangan zaman (Setyawan \& Saddhono, 2018: 78). Pendapat Setyawan dan Saddhono tersebut ditandai dengan fenomena budaya lokal makin tidak mendapat tempat dan makin dilupakan oleh masyarakat, khususnya masyarakat yang berasal dari kalangan pemuda. Oleh karenanya, urgensi dalam penelitian ini tidak hanya mengkaji simbol budaya dalam iklan, tetapi juga dalam rangka reaktualisasi dan penyebarluasan tentang unsur-unsur budaya lokal kepada masyarakat luas.

Iklan yang memasukkan unsur-unsur budaya lokal sebagai upaya untuk reaktualisasi budaya lokal kepada masyarakat sehingga budaya lokal akan tetap eksis dan tidak tergilas oleh budayabudaya asing yang sekarang juga sudah mulai marak di beberapa tayangan televisi. Salah satu iklan yang menyoroti dan mengungkap budaya lokal dalam tayangan iklan produknya adalah iklan produk Kuku Bima Ener-G. Kuku Bima Ener-G adalah salah satu produk minuman energi yang diproduksi oleh PT. Sido Muncul. Iklan dengan tema konten lokal dimaksudkan untuk mendekatkan brand suatu produk dengan keseharian masyarakat (Untoro, 2017: 108). Kuku Bima Ener-G dalam membuat iklan selalu konsisten dengan memasukkan unsur-unsur budaya lokal dari daerah-daerah yang terdapat di Indonesia. 
Serial iklan televisi Kuku Bima Energi versi Mari Berwisata di Negeri Sendiri merupakan serial iklan yang cukup unik, yaitu dikemas dengan memasukkan unsur promosi wisata dan budaya beberapa daerah di tanah air sehingga seakan-akan menjadi iklan pariwisata (Sulaiman \& Murtana, 2015: 81). Penelitian Sulaiman dan Murtana tersebut menjadi dasar peneliti untuk meneliti lebih mendalam tentang unsur-unsur budaya lokal yang terdapat dalam iklan Kuku Bima Ener-G.

Unsur-unsur kebudayaan yang dimasukkan ke dalam iklan Kuku Bima Ener-G sangatlah banyak, tidak hanya tari dan jenis kesenian, tetapi juga unsur-unsur budaya lainnya, seperti makanan tradisional, senjata tradisional, dan pakaian adat daerah. Bahkan, ada versi iklan Kuku Bima Ener$G$ yang menampilkan beberapa simbol budaya dari Keraton Surakarta. Keraton Surakarta merupakan salah satu sumber budaya Jawa. Keraton Surakarta juga menjadi rujukan dan tolok ukur masyarakat dalam menjalankan setiap aktivitas yang berkaitan dengan adat-budaya Jawa, seperti aturan dalam hal busana adat, kesenian, upacara, dan masih banyak yang lainnya (Mariati, 2018: 48). Hal tersebut tidak terlepas dari peran Keraton Surakarta sebagai artefak hidup yang sampai sekarang masih eksis menjalankan aktivitas adat dan budaya yang bersumber dari ajaran para leluhur, khususnya leluhur Kerajaan Jawa, yaitu Kerajaan Mataram.

Penelitian ini difokuskan untuk mengkaji makna simbol budaya Keraton Surakarta dalam iklan televisi Kuku Bima Ener-G versi Visit Jawa Tengah dengan menggunakan pendekatan semiotika. Alasan pemilihan iklan tersebut menjadi objek kajian dalam penelitian ini, pertama karena dalam iklan tersebut ditampilkan beberapa bentuk kebudayaan Jawa yang bersumber dari Keraton Surakarta yang di dalamnya memuat beberapa makna, baik makna yang tersurat (denotatif) maupun makna yang tersirat (konotatif). Kedua, simbol budaya yang diangkat dalam iklan tersebut mengacu pada budaya Keraton Surakarta yang notabene merupakan sumber budaya adilubung. Keraton Surakarta merupakan sumber adat istiadat Jawa karena Keraton Surakarta merupakan salah satu ahli waris budaya Kerajaan Jawa terdahulu, yaitu Keraton Mataram Islam. Jadi, dengan menganalisis makna simbol budaya Keraton Surakarta dapat diketahui adat-istiadat masyarakat Jawa secara umum. Ketiga, iklan Kuku Bima Ener-G versi Visit Jawa Tengah belum pernah dijadikan objek penelitian oleh peneliti lain sehingga hasil penelitian yang dilakukan oleh penulis diharapkan dapat menunjukkan suatu kebaruan dalam khasanah analisis periklanan di Indonesia, khususnya iklan yang memuat konten budaya lokal di dalamnya.

Analisis data dalam penelitian menggunakan teori semiotika Roland Barthes. Secara garis besar teori semiotika yang dikemukakan oleh Roland Barthes adalah tentang sistem tataran makna atau penalaran bertingkat. Konsep yang dikemukakan oleh Roland Barthes mengenai signifikansi dua tahap atau two order of signification. Pada tataran pertama ada sistem primer (denotasi) yang merupakan sistem pemahaman yang didasarkan pada kesepakatan sosial dan berlaku secara umum. Tataran kedua dalam analisis semiotika Roland Barthes adalah sistem sekunder yang merupakan pemahaman akan sebuah tanda didasarkan tidak hanya pada kesepakatan bersama yang berlaku tetapi juga bersandar pada adanya mitos yang dianut oleh masyarakat secara umum. Makna tataran kedua disebut dengan makna konotatif. Konotasi atau signifikansi pemaknaan tingkat kedua adalah untuk mengungkap makna yang terkandung dalam tanda-tanda (Haryono \& Putra, 2017: 3270). Analisis semiotika seperti yang dikemukakan oleh Roland Barthes relevan dengan tujuan dalam penelitian ini, yaitu untuk menganalisis makna simbol budaya Keraton Surakarta 
yang terdapat dalam iklan Kuku Bima Ener-G versi Visit Jawa Tengah. Analisis makna dari simbol budaya Keraton Surakarta dalam iklan Kuku Bima Ener-G versi Visit Jawa Tengah secara mendalam akan dikemukakan dalam bab selanjutnya dalam artikel ini.

\section{LANDASAN TEORI}

Analisis semiotika dikemukakan oleh beberapa ahli, di antaranya adalah ahli bahasa dari Perancis, Ferdinand de Saussure yang melihat tanda sebagai pertemuan antara bentuk dan makna. Saussure menggunakan istilah signifiant (penanda), untuk segi bentuk suatu tanda dan signifier (petanda) untuk segi maknanya (Hoed, 2011: 3). Selanjutnya, Roland Barthes adalah ahli yang meneruskan dan menyempurnakan teori yang dikemukakan oleh Ferdinand de Saussure. Roland Barthes meneruskan pemikiran tersebut dengan menekankan interaksi antara teks dengan pengalaman personal dan kultural penggunanya, interaksi antara konvensi yang dialami dan diharapkan oleh penggunanya. Konsep Barthes ini lebih dikenal dengan istilah two order of signification (Noor \& Wahyuningratna, 2017: 4). Konsep dua tataran makna dari Roland Barthes ini digunakan dalam penelitian untuk menganalisis simbol budaya yang terdapat dalam iklan Kuku Bima Ener-G versi Visit Jawa Tengah.

Analisis semiotika Roland Barthes membahas stratifikasi makna dalam sebuah tanda. Konsep stratifikasi makna Roland Barthes memandang bahwa dalam sebuah tanda terdapat dua tingkat makna, yaitu makna denotasi dan makna konotasi. Menurut Roland Barthes, signifikasi tahap pertama sebagai makna denotasi, yaitu makna paling nyata dari tanda. Makna denotasi membahas hubungan antara signifier (penanda) dan signified (petanda) di dalam sebuah tanda terhadap realitas eksternal (Situmeang, 2015: 117). Dari pendapat di atas dapat didefinisikan bahwa makna denotatif merupakan makna yang sebenarnya dari sebuah penanda.

Setelah makna denotatif sebagai signifikasi tahap pertama, Roland Barthes menggunakan istilah konotasi untuk menunjukkan signifikasi tahap kedua. Hal ini menggambarkan interaksi yang terjadi ketika tanda bertemu dengan perasaan atau emosi pembaca serta nilai-nilai kebudayaannya. Konotasi mempunyai makna yang subjektif atau paling tidak intersubjektif. Dengan kata lain, makna konotasi dipengaruhi oleh interpretasi dan pengalaman tiap-tiap individu sehingga dimungkinkan terdapat lebih dari satu pemaknaan. Berikut ini ditampilkan beberapa frame iklan Kuku Bima Ener-G versi Visit Jawa Tengah yang memuat simbol budaya Keraton Surakarta.

Iklan merupakan suatu alat berupa pesan yang digunakan untuk menawarkan suatu produk yang ditujukan kepada masyarakat lewat media. Hal tersebut sesuai dengan pendapat Kotler (2005: 278) bahwa salah satu tujuan iklan adalah bersifat informatif dan persuasif. Iklan adalah bentuk komunikasi yang efektif yang mempunyai tujuan persuasif dengan mengubah sikap atau perilaku penerima pesan. Bahasa dalam periklanan disampaikan dengan menggunakan simbol-simbol yang dapat merepresentasikan gambaran produk yang diiklankan. Iklan terbagi menjadi tiga kategori menurut sarana pengiklanannya, yaitu iklan media cetak, iklan media elektronik, dan iklan media luar ruang (Tjiptono, 2008: 243). Oleh karenanya, bahasa dan simbol dalam iklan disampaikan dapat melalui media elektronik (televisi dan radio) dan media cetak (brosur, majalah, baliho, ataupun surat kabar). Iklan menjadi media penyampaian informasi yang sangat terstruktur yang menggunakan elemen-elemen verbal maupun nonverbal.

Fungsi dan tujuan iklan pada hakikatnya sebagai bentuk komunikasi untuk menyampaikan suatu informasi. Menurut Robert W. Pollay (dalam Bungin, 2011: 115) iklan mempunyai dua fungsi, 
yaitu fungsi informasional dan transformasional. Fungsi transformasional merupakan iklan yang berusaha untuk mengubah sikap-sikap yang dimiliki oleh konsumen terhadap merek, pola-pola belanja, gaya hidup, teknik-teknik mencapai sukses, sedangkan fungsi informasional adalah iklan yang memberitahukan kepada konsumen tentang karakteristik produk. Fungsi iklan tidak hanya sebatas yang disebutkan oleh Robert W. Pollay tersebut, tetapi iklan juga dapat digunakan sebagai sarana mengenalkan dan mereaktualisasi budaya lokal kepada publik atau khalayak umum. Hal ini sesuai dengan survei yang dilakukan oleh Media Monitoring PT Surindo Utama tentang dampak iklan dari beberapa produk yang mereka teliti, ditemukan adanya fenomena bahwa iklan yang menggunakan identitas etnik lebih cepat diterima dan diingat oleh masyarakat (Haryono \& Putra, 2017: 3265). Penggunaan konsep iklan dengan tema budaya telah banyak digunakan oleh beberapa produk komersial seperti produk minuman berenergi Kuku Bima Ener-G, obat cair Tolak Angin, makanan instan Indomie, obat batuk Oskadon, dan masih banyak yang lainnya. Oleh karenanya, dalam penelitian ini dipilih iklan dari produk minuman Kuku Bima Ener-G sebagai objek penelitian karena memuat simbol budaya lokal, terutama tentang simbol budaya Keraton Surakarta.

Untuk menerjemahkan dan memaknai simbolsimbol budaya Keraton Surakarta dalam iklan menggunakan teori semiotika. Analisis semiotika merupakan sebuah kajian yang memfokuskan analisisnya pada tanda. Tanda menjadi konsep utama dalam analisis semiotika karena tanda dianggap dapat membantu seseorang untuk memaknai pesan dan maksud bahasa yang diharapkan oleh si penyampai pesan (Yulianto, 2017: 29). Dalam tanda terdapat makna yang dapat diinterpretasikan oleh manusia. Tanda menurut pandangan Danesi (2010: 7) dapat berbentuk visual, verbal, atau fisik yang ditangkap oleh indera manusia dan dapat merepresentasikan sesuatu atau makna selain dirinya. Mengacu pada pendapat Danesi, tanda dan simbol budaya dalam iklan Kuku Bima Ener-G versi Visit Jawa Tengah dapat dikategorikan dalam tanda bentuk visual. Melalui analisis semiotika, manusia dibantu untuk dapat merepresentasikan dan menafsirkan makna yang terkandung dalam sebuah tanda.

Roland Barthes menggunakan teori significantsignifie dan muncul dengan teori baru yang berkaitan dengan teori konotasi. Bila Saussure hanya menekankan pada penandaan dalam tataran denotatif, maka Roland Barthes menyempurnakan semiologi Saussure dengan mengembangkan sistem penandaan pada tingkat konotatif. Barthes juga melihat aspek lain dari penandaan, yaitu "mitos" yang menandai suatu masyarakat (Wirianto \& Girsang, 2016: 187). Dapat dikatakan bahwa perbedaan pokok antara semiotika Saussure dan Barthes adalah Barthes lebih menekankan teorinya pada mitos dan pada masyarakat budaya tertentu (bukan individual). Barthes mengemukakan bahwa semua hal yang dianggap wajar di dalam suatu masyarakat adalah hasil dari proses konotasi.

Semiotika Roland Barthes dikenal dengan teori signifikasi dua tahap atau two order of signification. Teori semiologi Roland Barthes, denotasi merupakan sistem signifikasi tahap pertama, sementara konotasi merupakan sistem signifikasi tahap kedua. Dalam pandangan Basarah (2017: 112) denotasi lebih diasosiasikan dengan ketertutupan makna dan dengan demikian merupakan sensor atau represi politis. Selanjutnya, konotasi identik dengan operasi ideologi yang disebutnya dengan mitologi (mitos) yang berfungsi untuk mengungkapkan dan memberikan pembenaran bagi nilai-nilai dominan yang berlaku dalam periode tertentu. Hal yang senada juga diungkapkan oleh Wirianto \& Girsang (2016: 187), bahwa makna denotasi merupakan makna yang sebenar- 
benarnya yang disepakati bersama secara sosial yang rujukannya pada realitas. Tanda konotatif merupakan tanda yang penandanya mempunyai keterbukaan makna atau makna yang implisit, tidak langsung, dan tidak pasti artinya terbuka kemungkinannya terhadap penafsiran-penafsiran baru. Masih membahas makna denotasi dan konotasi, Hidayah, Yarno, \& Hermoyo (2018: 38) mendefinisikan makna denotasi sebagai suatu kata yang maknanya bisa ditemukan dalam kamus. Denotasi mengungkapkan makna dari apa yang dilihat oleh mata, artinya, makna denotasi adalah makna sebenarnya. Selanjutnya, makna konotasi mempunyai makna yang subjektif dan bervariasi, dapat dikatakan bahwa makna konotasi bergantung bagaimana konotasi menggambarkannya. Mengacu dari beberapa pendapat ahli di atas, dapat ditarik suatu simpulan mengenai makna denotasi dan konotasi. Makna denotasi merupakan makna yang sebenar-benarnya sesuai dengan keadaan suatu objek atau tanda. Makna denotasi merupakan sebuah makna yang sudah menjadi kesepakatan bersama dari kelompok sosial tertentu dan sifatnya statis (tertutup). Di sisi lain, makna konotasi adalah makna yang terkandung dalam tanda-tanda, sifatnya terbuka, dinamis, dan bersifat subjektif, yaitu tergantung bagaimana seseorang dalam merepresentasikan serta menafsirkan makna konotasi tersebut. Jadi, melalui makna konotasi dimungkinkan timbul pemaknaan baru. Apabila digambarkan dalam sebuah bagan, pola semiotika Roland Barthes yang disebut dengan istilah signifikansi dua tahap atau two order signification dapat dilihat dalam bagan berikut.


Bagan 1.1 Alur Pemikiran Semiotika Roland Barthes

Dari bagan tersebut, dapat dijelaskan bahwa signifikasi tahap pertama merupakan hubungan antara signifier dan signified yang disebut dengan istilah denotasi atau makna sebenarnya. Signifikasi tahap kedua menggunakan istilah konotasi, yaitu makna yang subjektif atau paling tidak intersubjektif; yang berhubungan dengan misi, tanda bekerja melalui mitos. Mitos merupakan lapisan pertanda dan makna yang paling dalam (Vera, 2015:30). Dengan mengacu pada bagan tersebut, apabila seseorang menganalisis suatu tanda, pasti melalui interpretasi tahap pertama dan menemukan sebuah signifikasi atau makna tahap pertama (denotasi). Kemudian, seseorang harus mencari interpretasi selanjutnya, yaitu memasuki tahap signifikasi kedua untuk menemukan makna 
konotasi dan mitos dari suatu tanda yang dianalisis. Mitos merupakan pantulan struktur sosial dan hubungan sosial yang di dalamnya terkandung perasaan-perasaan mendasar yang umum dimiliki manusia. Mitos dapat menggambarkan peristiwa kesejarahan meskipun tidak dapat dikemukakan sebagai bukti sejarah dan juga lingkup sosial kemasyarakatan sebagai cerminan masyarakat pemilik mitos itu (Wewengkang, 2018: 107). Jadi, analisis semiotika Roland Barthes juga mengungkap mitos dari setiap simbol budaya yang dapat merepresentasikan budaya dan latar belakang masyarakat pemilik mitos.

Mengacu pada pemaparan mengenai teori semiotika dan iklan, penulis tertarik menggunakan teori semiotika Roland Barthes untuk menganalisis makna simbol budaya Keraton Surakarta yang terdapat dalam iklan Kuku Bima Ener-G versi Visit Jawa Tengah. Simbol-simbol budaya tersebut dapat berupa visualisasi beberapa unsur budaya Keraton Surakarta yang meliputi bangunan fisik keraton, prosesi upacara adat, benda pusaka, dan beberapa kesenian yang bersumber dari Keraton Surakarta. Penelitian tentang simbol budaya Keraton Surakarta dalam iklan Kuku Bima Ener$G$ versi Visit Jawa Tengah belum pernah ada. Jadi, hasil penelitian ini memiliki kebaruan dalam khasanah analisis semiotika.

\section{METODE PENELITIAN}

Penelitian ini berbentuk penelitian deskriptif kualitatif dengan menggunakan pendekatan semiotika. Pendekatan semiotika yang digunakan adalah teori semiotika Roland Barthes. Objek atau sumber data primer dalam penelitian ini adalah iklan televisi Kuku Bima Ener-G versi Visit Jawa Tengah. Sumber data sekunder diperoleh dari beberapa pustaka atau referensi yang memuat teori yang relevan dengan analisis data dalam penelitian ini, serta diambil dari hasil wawancara dengan para ahli. Teknik sampel yang digunakan adalah teknik purposive sampling atau teknik sampel bertujuan. Tujuan dipilihnya iklan tersebut dari beberapa iklan televisi Kuku Bima Ener-G karena dalam iklan tersebut terdapat beberapa adegan yang menampilkan potret budaya yang berasal dan bersumber dari Keraton Surakarta.

Teknik pengambilan data dalam penelitian ini menggunakan teknik simak dan catat, yaitu menyimak iklan Kuku Bima Ener-G versi Visit Jawa Tengah kemudian mencatat beberapa hal penting yang digunakan sebagai data dalam penelitian ini. Penulis juga melakukan wawancara dengan beberapa pakar, terutama pakar budaya Jawa di lingkungan keraton untuk mendapatkan data yang berkaitan dengan budaya dan kebudayaan yang bersumber dari Keraton Surakarta. Tahap analisis data dalam penelitian ini menggunakan analisis interaktif dan komparatif, dengan tahapan sebagai berikut: reduksi data (memilah data yang relevan dengan permasalahan dan diperlukan dalam kegiatan analisis data), sajian data (menyajikan data-data atau temuan dalam penelitian kemudian dianalisis dengan menggunakan pendekatan dan landasan teori yang sudah dipilih), dan penarikan simpulan (Moleong, 2014: 153). Terakhir untuk menguji validitas data dalam penelitian ini digunakan teknik triangulasi sumber data dan teknik triangulasi teori.

\section{PEMBAHASAN}

\section{Makna Simbol Budaya Keraton Surakarta dalam Iklan Kuku Bima Ener-G Versi Visit Jawa Tengah}

\section{Makna Simbol Tari Manipuri}

Potret budaya yang pertama adalah potret tentang Tari Manipuri. Tari Manipuri merupakan tarian karya GPH Prabuwinoto, Putra Pakubuwana IX. Tari Manipuri kalau dilihat dari 
geraknya merupakan sebuah tarian yang menggabungkan antara unsur tari India dan tari Jawa klasik. Gerak tariannya cenderung lincah dan rampak, tidak lambat, tetapi kadang halus seperti tari Jawa Klasik. Tari Manipuri menjadi salah satu ikon tari dari keraton Surakarta. Alasan pemilihan Tari Manipuri karena Tari Manipuri adalah salah satu tari tradisi dari keraton Surakarta yang ter- masuk ke dalam ragam tari yang dapat dikomersialkan, berbeda dengan tari-tari tradisi seperti Tari Bedhaya Ketawang dan Tari Srimpi yang merupakan tari yang digunakan dalam prosesi upacara adat keraton Surakarta. Representasi Tari Manipuri dalam iklan Kuku Bima Ener-G versi Visit Jawa Tengah dapat dilihat dalam frame berikut.



Frame 1. Tari Manipuri (00.00.09)

Makna denotatif, dalam frame tersebut ditampilkan oleh seorang wanita yang mengajari anak-anak tentang Tari Manipuri di sebuah halaman rumah yang memiliki arsitektur khas Jawa. Perempuan tersebut diperankan oleh Shanty, seorang artis wanita salah satu brand ambassador iklan Kuku Bima Ener-G. Terlihat dalam frame tersebut anak-anak yang memakai seragam, sangat riang dan antusias dalam belajar setiap gerakan Tari Manipuri.

Makna konotatif, dalam frame tersebut dimaksudkan bahwa Kuku Bima Ener-G sangat peduli terhadap budaya lokal. Kepedulian tersebut direpresentasikan oleh sosok wanita yang dengan senang hati mengajari tarian Manipuri kepada sekelompok anak-anak. Selain itu, melalui tari Manipuri yang merupakan tarian yang diciptakan dari campuran tarian bergaya India dan tarian Jawa klasik ingin ditampilkan bahwa dalam Kuku Bima Ener-G juga ditampilkan suatu proses akulturasi, yaitu sebuah jamu (warisan budaya lokal) yang dikemas dengan kemasan dan tampilan yang modern.

\section{Makna dari Simbol Bangunan Kamandungan dan Panggung Gedhe Sangga Buwana}

Bangunan keraton Jawa identik dengan bangunan yang memiliki simbol atau makna, seperti halnya bangunan yang terdapat di Keraton 
Surakarta. Dalam iklan Kuku Bima Ener-G versi Visit Jawa Tengah ditampilkan bangunan Keraton Surakarta, tepatnya adalah bangunan Kamandungan dan panggung Gedhe Sangga Buwana. Kedua bangunan tersebut merupakan bangunan yang menjadi ikon di Keraton Surakarta karena tidak ditemukan di keraton-keraton lain, termasuk Keraton Yogyakarta. Kori kamandungan adalah pintu dari pelataran kamandungan menuju palataran Sri Manganti. Bangunan ini dibangun oleh Sunan Pakubuwono IV pada tahun 1819 M. Atap kori kamandungan berbentuk joglo dua susun, pada bagian depan diberikan ornamen berupa "padu muka bale rata" berupa kepala raksasa dan dua naga yang saling berungkuran. Panggung Sangga Buwana merupakan bangunan yang bersifat privat dan sakral dengan tinggi 28 meter berfungsi sebagai menara pengawas dan sebagai tempat untuk bersemedi Sunan atau Raja Keraton Surakarta dalam pertemuan dengan penguasa laut kidul “Kanjeng Ratu Kidul” (Djumiko, 2016: 5). Bangunan kamandungan dan panggung gedhe sangga buwana dapat dilihat dalam frame iklan berikut.

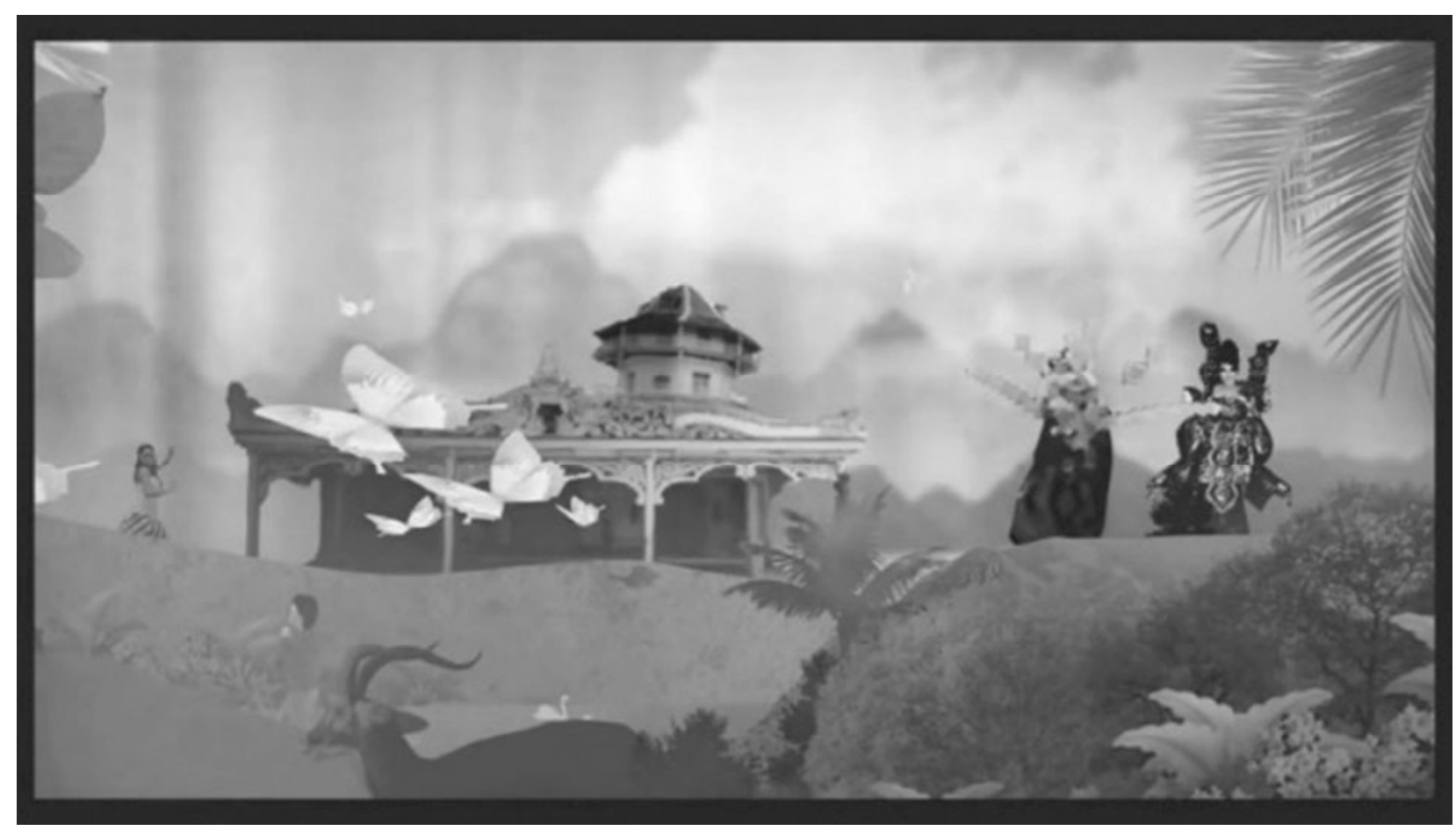

Frame 2. Panggung Sangga Buwana dan Kori Kamandungan (00.00.28)

Makna denotatif dalam frame tersebut ditampilkan potret oleh seorang yang sedang menari, kori kamandungan, panggung sangga buwana, dan dua orang yang sedang memakai kostum Solo Batik Carnival. Makna ikon tersebut adalah untuk memperkuat bahwa beberapa item budaya di atas berasal dari Kota Surakarta. Kota Surakarta merupakan salah satu kota yang terletak di Provinsi Jawa Tengah. Jadi, dengan menampilkan ikonikon di atas, secara tidak langsung sebagai sarana promosi tentang ciri khas atau ikon dari Provinsi Jawa Tengah.

Makna konotatif ditampilkan oleh dua bangunan ikonik dari Keraton Surakarta, yaitu Kamandungan dan Panggung Sangga Buwana yang tidak ditemukan di keraton-keraton lain secara tidak langsung ini memberikan arti kepada khalayak luas bahwa Kuku Bima mempunyai ciri khusus yang tidak ditemukan di produk minuman berenergi lainnya, yaitu rasanya yang variatif. 
Kuku Bima memiliki varian rasa yang banyak, di antaranya anggur, jeruk, jambu, mangga, nanas, kopi, original, dan susu soda. Varian rasa yang bervariasi dari Kuku Bima Ener-G tersebut tidak ditemukan di produk minuman energi lainnya.

\section{Makna Prosesi Upacara Kirab}

Keraton sebagai suatu entitas sosial masyarakat atau komunitas mempunyai kebudayaan sendiri. Di dalam masyarakat tersebut terjadi interaksi, baik secara individual, maupun secara kolektif (Prabowo, 2012: 39). Setiap kegiatan yang berkaitan dengan adat dan istiadat budaya keraton selalu dilaksanakan sesuai dengan kaidah atau aturan adat. Hal tersebut sudah menjadi pedoman hidup bagi masyarakat adat di lingkungan Keraton Surakarta. Apabila salah seorang masyarakat adat tidak mematuhi aturan adat yang berlaku, maka seseorang akan mendapatkan sebuah halad atau sesuatu yang buruk yang tidak diinginkan. Dalam iklan Kuku Bima Ener-G versi Visit Jawa Tengah ditemukan bentuk representasi upacara adat, yaitu kirab. Dalam upacara kirab tersebut terlihat beberapa orang yang berjalan beriringan dengan memakai busana adat serta membawa peranti upacara adat (dupa dan beberapa sesaji). Dalam frame iklan tersebut merepresentasikan masyarakat adat yang masih menaati peraturan hukum adat, utamanya adalah adat Keraton Surakarta yang berkaitan dengan pelaksanaan upacara kirab. Hukum adat tersebut dapat dilihat dari busana yang digunakan, yaitu harus menggunakan busana adat kejawaan (untuk abdi dalem memakai samir), membawa peranti upacara adat, dan harus sesuai dengan struktur atau urutannya. Hal tersebut dapat dilihat dalam frame iklan di bawah ini.

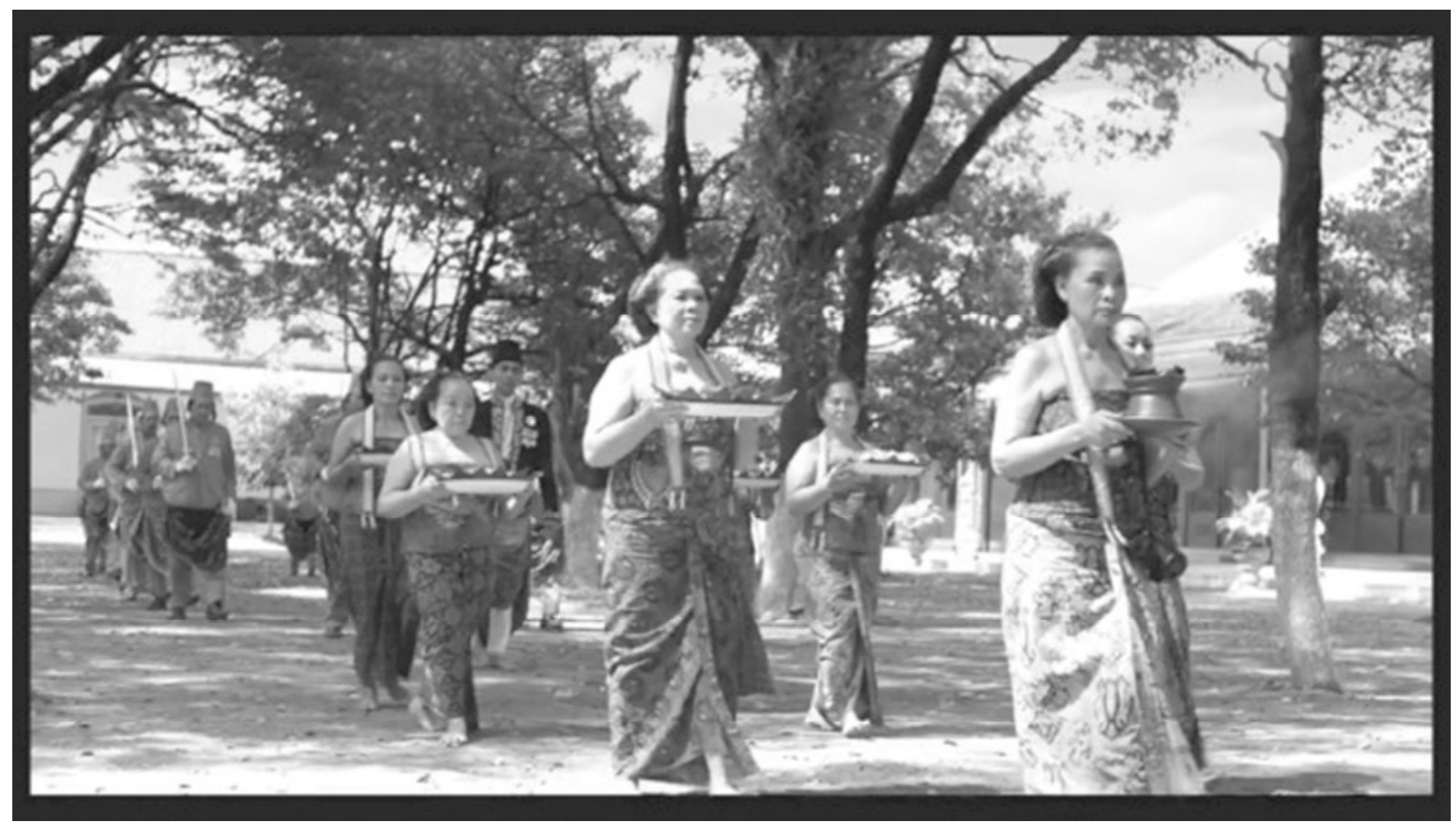

Frame 3. Potret Upacara Kirab (00.00.33)

Makna denotatif frame iklan di atas adalah menunjukkan sebuah prosesi kirab yang dilaksanakan oleh para abdi dalem Keraton Surakarta.
Prosesi kirab tersebut dilaksanakan sesuai dengan aturan adat keraton, yaitu memakai busana adat Jawa dan menggunakan peranti adat, yaitu dupa 
dan rangkaian sesaji yang kesemuanya memiliki makna. Semua aturan tersebut harus ditaati oleh masyarakat adat, apalagi ketika menjalankan aktivitas yang berkaitan dengan prosesi upacara adat.

Makna konotatif frame tersebut adalah tentang sebuah aturan atau tata cara upacara adat Keraton Surakarta yang harus ditaati oleh semua masyarakat adat. Hal yang sama juga terdapat dalam Kuku Bima Ener-G, yaitu tentang tata cara atau aturan pada saat minum atau menggunakan produk Kuku Bima Ener-G. Kuku Bima Ener-G merupakan sebuah suplemen atau minuman berenergi yang dibuat dengan mencampurkan beberapa bahan kimia. Lazimnya minuman energi digunakan oleh olahragawan atau pekerja yang membutuhkan tenaga lebih, bukan untuk konsumsi harian, apalagi dikonsumsi rutin dengan takaran yang berlebihan. Hal ini dapat menimbulkan efek yang tidak baik bagi kesehatan. Aturan pemakaian atau penggunaan Kuku Bima Ener-G adalah diminum maksimal 3 saset setiap hari bagi orang dewasa, apabila dikonsumsi lebih dari itu dapat membahayakan tubuh terutama bagi ginjal.

\section{Makna Simbol Nasi Tumpeng Sari}

Simbol budaya selanjutnya yang berkaitan dengan Keraton Surakarta dan ditampilkan dalam iklan Kuku Bima Ener-G versi Visit Jawa Tengah adalah nasi tumpeng sari. Nasi tumpeng sari merupakan salah satu makanan khas dari Jawa Tengah yang berbentuk kerucut. Tumpeng sari digunakan dalam berbagai upacara adat, seperti upacara garebek di Keraton Surakarta, upacara tedhak siten, upacara bersih desa, dan beberapa upacara adat lainnya. Filosofi tumpeng merupakan simbol dari gunung yang menunjukkan bahwa tumpeng sari adalah interpretasi terhadap doa manusia yang menuju ke atas (Tuhan), tumuju marang pengeran (tertuju kepada Tuhan); dedonga anteng, meneng, methentheng (berdoa dengan tenang, diam, dan teguh) (Pradanta, Sudardi, \& Subiyantoro, 2015: 161). Penggambaran nasi tumpeng sari dalam iklan Kuku Bima Ener-G versi Visit Jawa Tengah dapat dilihat dalam frame iklan berikut.

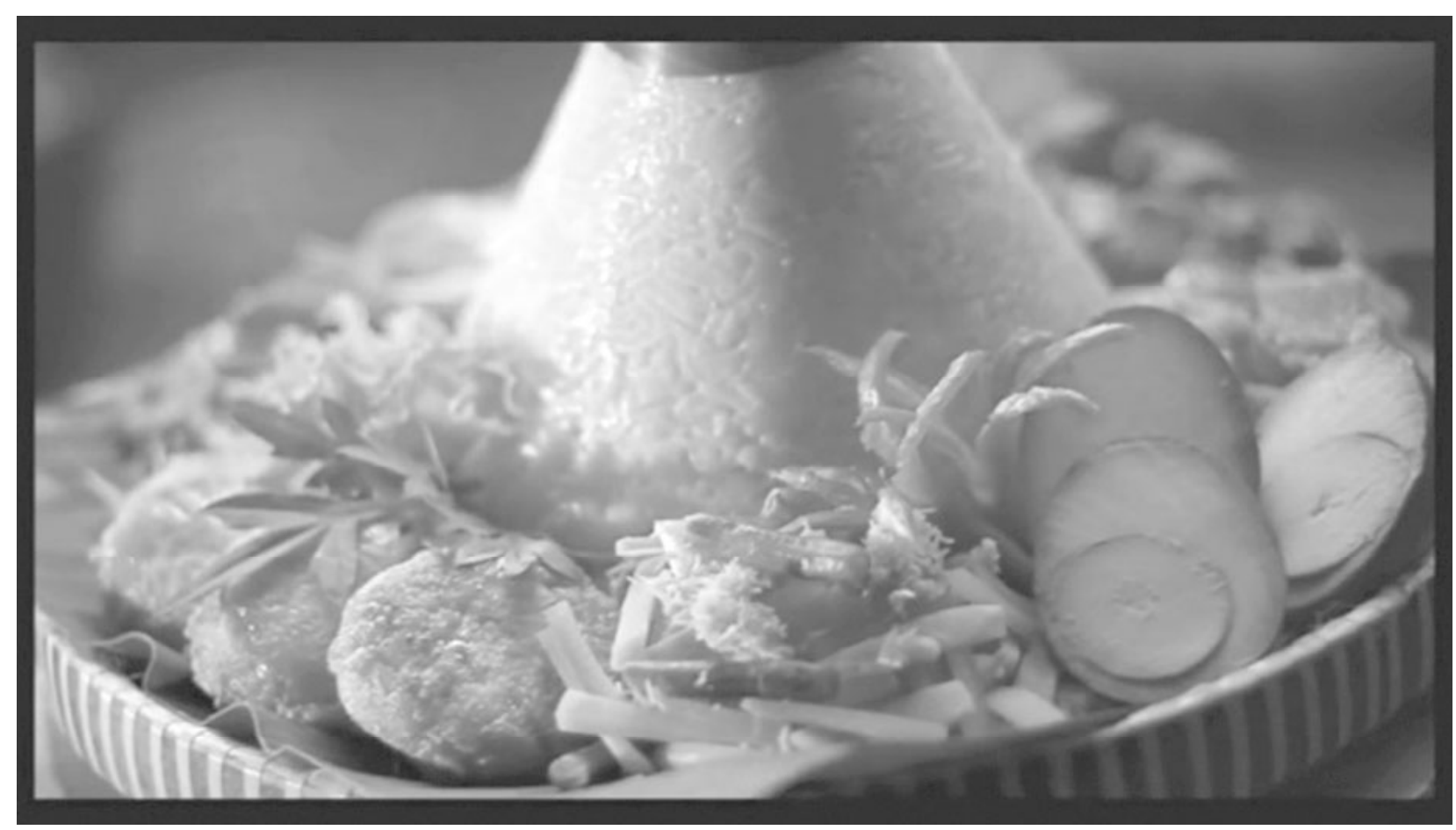

Frame 4. Potret Nasi Tumpeng Sari (00.01.04) 
Makna denotatif dalam frame iklan tersebut ditampilkan oleh potret tumpeng yang menjadi salah satu makanan khas masyarakat Jawa. Tumpeng selalu digunakan dalam berbagai upacara adat masyarakat Jawa, seperti upacara garebek di Keraton Surakarta, upacara tedhak siten, upacara bersib desa, dan beberapa upacara lainnya. Makna tumpeng dalam iklan tersebut adalah untuk menguatkan bahwa tumpeng merupakan salah satu masakan khas masyarakat Jawa, khususnya Jawa Tengah lengkap dengan berbagai peranti isiannya.

Makna konotatif tumpeng dalam masyarakat Jawa merepresentasikan sebuah doa yang ditujukan kepada Tuhan. Segala macam dan ragam yang ada di dunia ini adalah bersumber dari Yang Satu atau Tuhan, dilambangkan sebagai tumpeng berbentuk kerucut di atas. Makna lainnya bahwa segala macam doa merupakan upaya sinergisme kepada Tuhan Yang Maha Esa. Oleh sebab itu, di bagian bawah tumpeng bentuknya lebar dan besar, makin ke atas makin kerucut sehingga bertemu dalam satu titik. Satu titik itu menjadi pucuk atau penyebab dari segala yang ada, yaitu Tuhan sebagai pusat dari segala pusat kehidupan. Dengan menggunakan tumpeng dapat dimaknai merupakan harapan atau doa dari produsen Kuku Bima Ener-G melalui iklan tersebut agar produk Kuku Bima Ener-G menjadi produk yang laku dan laris di pasaran. Isian tumpeng yang bermacam-macam melambangkan varian rasa Kuku Bima Ener-G yang bermacam-macam.

\section{Makna Simbol Pusaka Keris Gaya Surakarta}

Selain beberapa hal di atas, masih terdapat lagi simbol budaya yang berasal dari Keraton Surakarta dalam iklan Kuku Bima Ener-G versi Visit Jawa Tengah, yaitu senjata keris. Keris merupakan salah satu pusaka yang dimiliki oleh masyarakat Jawa. Keris dibuat dari besi yang ditempa oleh seorang ahli keris yang bernama Mpu. Setiap keris memiliki pamor dan jumlah lekukan (luk) yang berbeda dan jumlahnya selalu ganjil. Keris gaya Surakarta dan keris gaya Yogyakarta memiliki perbedaan bila dilihat dari bentuk fisiknya. Keris melambangkan semangat dan kekuatan. Dalam iklan Kuku Bima Ener-G versi Visit Jawa Tengah ditampilkan potret keris yang dipegang oleh atlet binaragawan, yaitu Ade Ray yang dapat dilihat dalam frame iklan berikut ini.



Frame 5. Pusaka Keris Melambangkan Kekuatan (00.01.16) 
Makna denotatif frame iklan di atas ditampilkan seorang atlet binaragawan Ade Ray. Ade Ray tampak mantap dalam memegang dan memandang pusaka keris gaya Surakarta. Dari sini dapat dilihat bahwa Ade Ray memiliki sebuah kekaguman dan kebanggaan terhadap senjata keris yang merupakan senjata tradisional dari Keraton Surakarta.

Makna konotatif frame di atas ditampilkan keris dan atlet binaragawan Ade Ray. Keris melambangkan kekuatan dan semangat, begitupun Ade Ray, seorang atlet binaragawan yang juga melambangkan kekuatan seorang pria. Produser iklan menampilkan keduanya sebagai lambang kekuatan, yaitu Kuku Bima Ener-G merupakan minuman energi yang digunakan untuk menambah kekuatan khususnya bagi pria.

Keris secara mitos dilambangkan sebagai bentuk dari isi dan kesaktian. Terkait dengan hal ini, sebuah keris dapat diartikan menyimpan sebuah rahasia kesaktian yang dapat digunakan sebagai senjata. Bahkan, tidak jarang keris dapat digunakan sebagai jimat bagi seseorang. Adakalanya keris dianggap sebagai benda yang keramat sehingga orang yang memiliki keris akan merawatnya dengan serangkaian ritual. Keris juga menjadi barang pusaka bagi sekelompok orang tertentu.

\section{PENUTUP}

Iklan merupakan salah satu sarana yang digunakan oleh produsen suatu produk untuk memasarkan produknya. Iklan Kuku Bima Ener$G$ versi Visit Jawa Tengah mengandung simbol budaya yang diambil dari budaya yang terdapat di Keraton Surakarta. Simbol budaya Keraton Surakarta yang terdapat di dalam iklan Kuku Bima Ener-G versi Visit Jawa Tengah dianalisis dengan menggunakan teori semiotika Roland Barthes. Teori semiotika Roland Barthes mengemukakan teori stratifikasi makna dari sebuah tanda, makna denotasi sebagai signifikasi tahap pertama, makna konotasi sebagai signifikasi tahap kedua. Dalam iklan Kuku Bima Ener-G versi Visit Jawa Tengah terdapat 5 frame yang merepresentasikan budaya Keraton Surakarta. Kelima frame tersebut menampilkan tentang Tari Manipuri, bangunan panggung Sangga Buwana dan Kori Kamandungan, prosesi upacara kirab, makanan tradisional tumpeng asri, dan keris. Dari tiap-tiap simbol budaya tersebut terdapat makna-makna yang ingin disampaikan oleh produsen Kuku Bima Ener-G kepada khalayak luas. Makna-makna tersebut terdiri dari makna denotatif dan makna konotatif. Selain itu, dengan memasukkan beberapa simbol budaya dari Keraton Surakarta dalam iklan Kuku Bima EnerG juga dapat digunakan sebagai sarana promosi kearifan lokal budaya yang sekarang sudah mulai memudar di kalangan masyarakat. Tari Manipuri menggambarkan sebuah tarian upacara persembahan syukur kepada Tuhan Yang Mahakuasa atas berkah kehidupan di dunia, Surakarta. Tumpeng sendiri merupakan simbol dari gunung yang menunjukkan bahwa tumpeng sari adalah interpretasi terhadap doa manusia kepada Sang Pencipta. Keris sebagai simbol kesaktian dan senjata bagi seorang laki-laki.

\section{DAFTAR PUSTAKA}

Basarah, Finy. 2017. "Feminisme Eksistensialis Tokoh Katniss Everdeen dalam Serial Film The Hunger Games (Analisis Semiotika Roland Barthes)". Jurnal Semiotika, Vol. 11, No. 1, 2017. Bungin, Burhan. 2011. Kontruksi Sosial Media Massa: Kekuatan Pengarub Media Massa, Iklan Televisi, dan Keputusan Konsumen serta Kritik terhadap Peter L. Berger dan Thomas Luckmain. Jakarta: Penerbit Kencana.

Danesi, Marcel. 2010. Pengantar Memahami Semiotika Media. Yogyakarta: Jalasutra.

Djumiko. 2016. "Sikap Bangunan Baru dalam Mewujudkan Karakter Arsitektural Kota 
Surakarta Studi Kasus di Jalan Slamet Riyadi”. Jurnal Teknik. Arsitektur, Vol. 19, No. 23, 2016.

Haryono, Sinta \& Putra, Dedi. 2017. "Identitas Budaya Indonesia: Analisis Semiotika Roland Barthes dalam Iklan Aqua Versi "Temukan Indonesiamu". E-Proceeding of Management: Vol. 4, No. 3, Desember 2017.

Hidayah, N., Yarno, Y., \& Hermoyo, R. P. 2018. "Representasi Budaya Jawa dan Barat dalam Novel Rahvayana Karya Sujiwo Tejo”. Stilistika Jurnal Pendidikan Bahasa dan Sastra, 9(2).

Hoed, Benny H. 2011. Dampak Komunikasi Periklanan, Sebuah Ancangan dari Segi Semiotika, (SENI Jurnal Pengetabuan dan Pencipta Seni). Yogyakarta: BPISI.

Kotler, Philip. 2005. Manajemen Pemasaran. Jilid Pertama dan Kedua. Jakarta: PT. Indeks Kelompok Gramedia.

Malika, Ika \& Lestari, Petri. 2018. "Analisis Semiotika dalam Iklan "Fair and Lovely" versi Nikah atau S2. Jurnal Egaliter, Vol. 1, No. 2, Maret 2018.

Mariati, S. 2018. "Membaca Bekisar Merah, Mengeksplorasi Nilai-Nilai Budaya Jawa". Jurnal Semiotika, 7(1), 47-55.

Moleong, Lexy J. 2014. Metodologi Penelitian Kualitatif (Edisi Revisi). Bandung: PT Remaja Rosdakarya.

Morrisan, dkk. 2010. Teori Komunikasi Massa. Bogor: Penerbit Ghalia Indonesia.

Noor, Firdaus \& Wahyuningratna, Ratu. 2017. "Representasi Sensualitas Perempuan dalam Iklan New Era Boots di Televisi (Kajian Semiotika Roland Barthes)". Jurnal IkraithHumaniorta, Vol. 1, No. 2, November 2017.

Prabowo, R. Adi. 2012. "Perilaku Ritual Mitis Abdi Dalem Keraton Kasunanan Surakarta (Sebuah Dialektika Sosiologi Budaya)". Jurnal Dewa Ruci, Vol. 8, No. 1, 2012.
Pradanta, Sukmawan; Sudardi, Bani; \& Subiyantoro, Slamet. 2015. "Kajian Nilai-nilai Budaya Jawa dalam Tradisi Bancaan Weton di Kota Surakarta (Sebuah Kajian Simbolisme dalam Budaya Jawa)". Jurnal Lingua, Vol. 12, No. 2, September 2015.

Setyawan, Bagus W. \& Saddhono, Kundharu. 2018. "Ceprotan Performing Art: A Traditional Folkart Based on Urband Legend". Harmonia: Journal of Arts Research and Education 18 (1) (2018), 70-76.

Situmeang, Ilona. 2015. 'Representasi Wanita pada Iklan Televisi Wardah Cosmetic (Analisis Semiotik Roland Barthes Wardah Inspiring Beauty Versi True Colours)". Jurnal Semiotika, Vol. 9, No. 1, 2015.

Sulaiman, Annas \& Murtana, I Nyoman. 2015. "Strategi Visual Iklan Televisi Kuku Bima Energi Produksi PT. Sido Muncul Semarang”. Jurnal Gelar: Jurnal Seni Budaya, Vol. 13, No 1, Juli 2015.

Tjiptono, Fandy. 2008. Strategi Pemasaran. Edisi Ketiga. Yogyakarta: Andi Publisher.

Untoro, Ratun. 2017. "Penggambaran Alam dalam Sastra Jawa Kuno dan Jawa Modern sebagai Promosi Wisata”. Jurnal Kadera Bahasa, Vol. 9, No. 2, 2017.

Vera, Nawiroh. 2015. Semiotika dalam Riset Komunikasi. Bogor: Penerbit Ghalia Indonesia. Wewengkang, Nontje Deisye. 2018. "Makna Budaya dalam Mitos di Minahasa”. Jurnal Kadera Bahasa, Vol. 10, No. 2, 2018.

Wirianto, Ricky \& Girsang, Lasmery. 2016. "Representasi Rasisme pada Film "12 Years $A$ Slave" (Analisis Semiotika Roland Barthes)". Jurnal Semiotika, Vol. 10, No. 1, 2016.

Yulianto, Agus. 2017. "Interpretasi Simbol dalam Cerpen Corat-Coret di Toilet Karya Eka Kurniawan”. Jurnal Kadera Bahasa, Vol. 9, No. 1, 2017. 